\title{
Analysis of multiple virus-infected grapevine plant reveals persistence but uneven virus distribution
}

\author{
P. KOMÍNEK ${ }^{1}$, M. GLASA ${ }^{2}$ M. KOMÍNKOVÁ ${ }^{1}$
}

${ }^{1}$ Crop Research Institute, Drnovska 507, 16106 Prague-Ruzyne, Czech Republic; ${ }^{2}$ Institute of Virology, Slovak Academy of Sciences, Bratislava, Slovak Republic

\begin{abstract}
Summary. - LN33 grapevine plants were artificially inoculated with budwoods originating from a field-cultivated Traminer grapevine which was naturally infected with Grapevine leafroll-associated virus 1 (GLRaV-1), Grapevine virus A (GVA), Grapevine virus B (GVB), Rupestris stem pitting-associated virus (RSPaV), and an unclassified tymovirus. Four years after inoculation, a comparison of the cane weights between healthy and infected grapevines did not show any significant difference. Corky bark symptoms or destructive effects of GVB infection never appeared on the infected grapevines. Dormant canes, sampled before the beginning of the vegetation period, were used for detection of grapevine viruses by ELISA or RT-PCR. ELISA turned out unexpectedly to be more effective than RT-PCR for detecting GLRaV-1 probably due to an insufficient specificity of the primers used, not reflecting the actual genetic variability of the virus. Distribution of viruses in the infected grapevines showed a different degree of irregularity in dependence on individual viruses. Therefore, in order to properly verify the sanitary status of grapevines under testing, several random samples from different parts of a tested plant have to be analyzed.
\end{abstract}

Key words: grapevine; virus; corky bark; ELISA; RT-PCR

\section{Introduction}

Grapevine (Vitis vinifera) is one of the most virus-infected of all cultivated perennial plants. To date, 58 viruses belonging to 21 different genera have been described (Martelli and Boudon-Padieu, 2006). Multiple infections of the grapevine with two or more viruses are a common phenomenon, often resulting in both the aggravation of symptoms and in yield losses (Nassuth et al., 2000; Dovas and Katis, 2003).

E-mail: kominek@vurv.cz; fax: +420233-311592.

Abbreviations: GAMaV = Grapevine asteroid mosaic-associated virus; GFkV = Grapevine fleck virus; GLRaV-1 = Grapevine leafroll-associated virus 1; GRGV = Grapevine red globe virus; GRVFV $=$ Grapevine rupestris vein feathering virus; GVA = Grapevine virus $\mathrm{A} ; \mathrm{GVB}=$ Grapevine virus $\mathrm{B} ; \mathrm{RSPaV}=$ Rupestris stem pitting-associated virus
Plant viruses, in particular those infecting perennial crops, have a great potential for genetic variation. High mutation rate is an important prerequisite for the survival and competitiveness of viruses, as it constitutes the basis of viral adaptation (Garcia-Arenal et al., 2001).

During our previous field survey (Komínek, 2008), a grapevine plant (cv. Traminer) infected with five different viruses, namely GLRaV-1, GVA, GVB, RSPaV, and an unclassified tymovirus (a member of the family Tymoviridae), was found. GLRaV-1 (the genus Ampelovirus, the family Closteroviridae) is one of viruses responsible for leafroll disease of grapevine, which causes significant economic losses worldwide whenever the grapevine is cultivated (Habili et al., 2007). GVA and GVB belong to the genus Vitivirus, the family Flexiviridae (Adams et al., 2004). GVA is associated with the Kober stem grooving syndrome, part of rugose wood disease, which is one of the most widespread and economically important virus diseases of the grapevine. GVB is the putative agent of the corky bark syndrome of the rugose wood complex (Saldarelli et 
al., 1996). RSPaV belongs to the genus Foveavirus, the family Flexiviridae (Meng et al., 1998). Its role in rugose wood complex disease has not yet been fully revealed (Habili et al., 2006). To date, four tymoviruses are known to infect grapevine, namely Grapevine fleck virus (GFkV) and Grapevine red globe virus (GRGV) from the genus Maculavirus, and Grapevine rupestris vein feathering virus (GRVFV) and Grapevine asteroid mosaic-associated virus (GAMaV), two tentative members of the genus Marafivirus (Martelli et al., 2002).

In this work, LN33 grapevine was experimentally infected with GLRaV-1, GVA, GVB, RSPaV, and an unclassified tymovirus, and four years later the effect of multiple virus infection on the growth of the grapevine, the persistence and distribution of individual viruses within the plants was determined.

\section{Material and Methods}

Plant material. A 30-year-old grapevine (cv. Traminer) showing leafroll and mosaic symptoms and presence of GLRaV-1, GVA, GVB, RSPaV and an unidentified tymovirus, found in 2004 in a private garden in Modrice, Czech Republic (Komínek, 2008), was used as the virus source. Virus-free grapevine LN33 (Couderc 1613 x Thompson seedless) was obtained from the Mediterranean Agronomic Institute Valenzano, Bari, Italy, and cultivated in a screenhouse under EPPO standard conditions excluding any virus reinfection (Anonymous, 2008). One-year-old LN33 plants were inoculated by grafting of budwoods from the multiple virus-infected Traminer grapevine at the beginning of the vegetation period. Simultaneously, plants of cv. Traminer and healthy LN33 were raised by rooting of cuttings as positive and negative controls, respectively. The grapevines were cultivated in a screenhouse in 501 containers. One-year-old new shoots were positioned vertically, reaching about two meters in height. Symp- toms on the leaves and the plant habit of all three experimental series were evaluated.

ELISA was employed for detection of GLRaV-1, GVA, and GVB using specific antibodies from Agritest Valenzano, Bari, Italy. This method could not be applied to RSPaV and tymovirus due to the unavailability of respective commercial antisera.

$R T-P C R$ was used for detection of all the five tested viruses. Total RNA was isolated from dormant shoots using the RNeasy Plant Mini Kit and RT-PCR was performed using the OneStep RT-PCR Kit (both from Qiagen) and specific primers and cycling conditions (Table 1).

Testing of plants for viruses. Virus distribution in infected LN33 plants was analyzed four years after the graft inoculation by the methods given above. Two shoots from dormant canes were randomly selected in March and analyzed. Each shoot was divided into four sections about $0.5 \mathrm{~m}$ long, designated A (bottom) to D (top). Traminer and a healthy LN33 plants served as positive and negative controls, respectively.

\section{Results and Discussion}

\section{Growth of multiple virus-infected plants}

Six weeks after grafting of the infected Traminer budwoods onto healthy LN33 plants, shock symptoms appeared. The leaves were smaller and bronze, showing symptoms of deformation and shape changes. The growth of infected plants was reduced (Fig. 1). Some recovery was observed on the plants after the second vegetation period, when the symptoms became milder (Fig. 2). In the following vegetation periods the recovered plants reached in growth healthy plants, producing about ten long shoots every year.

Weighing of the canes of infected plants after the fourth vegetation period during winter pruning showed a mild but non-significant decrease in weight as compared with healthy LN33 plants (data not shown).

Table 1. RT-PCRs used for detection of grapevine viruses

\begin{tabular}{|c|c|c|c|c|}
\hline Virus & Primers $(\mathrm{A} / \mathrm{S})$ & $\begin{array}{l}\text { Amplicon } \\
\text { size (bp) }\end{array}$ & Cycling conditions & Reference \\
\hline GLRaV-1 & 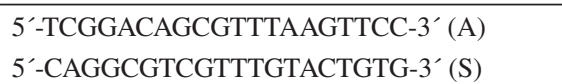 & 540 & $\begin{array}{l}45^{\circ} \mathrm{C} / 45 \mathrm{mins}, 95^{\circ} \mathrm{C} / 15 \mathrm{mins}, 40 \times\left(94^{\circ} \mathrm{C} / 55 \text { secs, }\right. \\
\left.55^{\circ} \mathrm{C} / 55 \mathrm{secs}, 72^{\circ} \mathrm{C} / 55 \mathrm{secs}\right), 72^{\circ} \mathrm{C} / 10 \mathrm{mins}\end{array}$ & $\begin{array}{l}\text { Komínek et al., } \\
2005\end{array}$ \\
\hline & $\begin{array}{l}\text { 5'-TGGCATCGTTGCTAAATTGAG-3 (A) } \\
5^{\prime} \text {-AATCCTATGCGTCAGTATGC-3' (S) }\end{array}$ & 175 & $\begin{array}{l}45^{\circ} \mathrm{C} / 45 \text { mins, } 95^{\circ} \mathrm{C} / 15 \mathrm{mins}, 40 \times\left(94^{\circ} \mathrm{C} / 30 \text { secs, }\right. \\
\left.53^{\circ} \mathrm{C} / 30 \mathrm{~s}, 72^{\circ} \mathrm{C} / 1 \mathrm{~min}\right), 72^{\circ} \mathrm{C} / 10 \mathrm{mins}\end{array}$ & $\begin{array}{l}\text { Habili et al., } \\
2003\end{array}$ \\
\hline GVA & 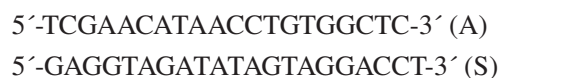 & 271 & $\begin{array}{l}45^{\circ} \mathrm{C} / 45 \mathrm{mins}, 95^{\circ} \mathrm{C} / 15 \mathrm{mins}, 40 \times\left(94^{\circ} \mathrm{C} / 45 \mathrm{secs},\right. \\
\left.50^{\circ} \mathrm{C} / 45 \mathrm{secs}, 72^{\circ} \mathrm{C} / 1 \mathrm{~min}\right), 72^{\circ} \mathrm{C} / 10 \mathrm{mins}\end{array}$ & $\begin{array}{l}\text { Goszczynski and } \\
\text { Jooste, } 2003\end{array}$ \\
\hline GVB & $\begin{array}{l}5^{\prime} \text {-GTGCTAAGAACGTCTTCACAGC-3' (A) } \\
\text { 5'-AGTAGCCCTTCGTTTAGCCGC-3' }^{\prime} \text { (S) }\end{array}$ & 158 & $\begin{array}{l}45^{\circ} \mathrm{C} / 45 \mathrm{mins}, 95^{\circ} \mathrm{C} / 15 \mathrm{mins}, 40 \times\left(94^{\circ} \mathrm{C} / 45 \mathrm{secs},\right. \\
\left.50^{\circ} \mathrm{C} / 45 \mathrm{secs}, 72^{\circ} \mathrm{C} / 1 \mathrm{~min}\right), 72^{\circ} \mathrm{C} / 10 \mathrm{mins}\end{array}$ & $\begin{array}{l}\text { Minafra and } \\
\text { Hadidi, } 1994\end{array}$ \\
\hline RSPaV & $\begin{array}{l}5^{\prime} \text {-GGTTTCTTAAAGATCCCTTCTTTG-3' (A) } \\
5^{\prime} \text {-CACAGGCATTTGCACAGAATC-3' (S) }\end{array}$ & 432 & $\begin{array}{l}45^{\circ} \mathrm{C} / 45 \text { mins, } 95^{\circ} \mathrm{C} / 15 \mathrm{mins}, 40 \times\left(94^{\circ} \mathrm{C} / 55 \mathrm{secs},\right. \\
\left.50^{\circ} \mathrm{C} / 55 \mathrm{secs}, 72^{\circ} \mathrm{C} / 55 \mathrm{secs}\right), 72^{\circ} \mathrm{C} / 10 \mathrm{mins}\end{array}$ & This study \\
\hline Tymovirus & 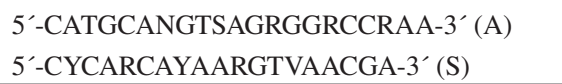 & 386 & $\begin{array}{l}45^{\circ} \mathrm{C} / 45 \text { mins, } 95^{\circ} \mathrm{C} / 15 \mathrm{mins}, 40 \times\left(94^{\circ} \mathrm{C} / 55 \mathrm{secs},\right. \\
\left.55^{\circ} \mathrm{C} / 55 \text { secs, } 72^{\circ} \mathrm{C} / 55 \mathrm{secs}\right), 72^{\circ} \mathrm{C} / 10 \mathrm{mins}\end{array}$ & $\begin{array}{l}\text { Sabanadzovic et } \\
\text { al., } 2000\end{array}$ \\
\hline
\end{tabular}

$\mathrm{A}=$ antisense, $\mathrm{S}=$ sense. 


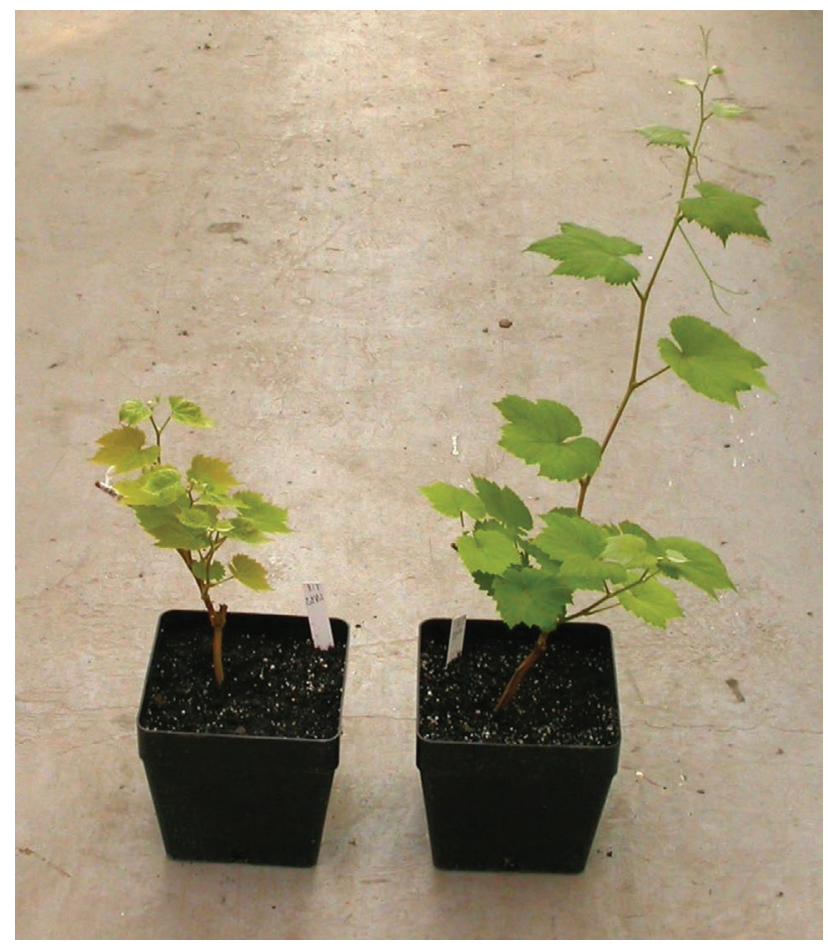

Fig. 1

Symptoms on a multiple virus-infected LN33 grapevine plant Six weeks after virus inoculation. Infected plant (left), healthy plant (right).

Missing corky bark symptoms in multiple virus-infected plants

The LN33 grapevine is widely used as indicator of GVB, where the appearance of corky bark symptoms is considered a definitive proof of the presence of GVB (Saldarelli et al., 1996). Interestingly, although the presence of GVB in the multiple virus-infected plants used in this study was repeatedly confirmed by ELISA, RT-PCR, and sequencing (data not shown), corky bark symptoms were not observed; not even in the first year after infection, when other severe symptoms occurred.

GVB is considered to have severe effects on infected grapevines, causing extensive necrosis and a complete vine decline in LN33 or a reduction of growth in other genotypes (Rosa, 2007). However, our results do not correspond to these findings. The only symptom we observed in LN33 was a leafroll, probably caused by GLRaV-1 (Fig. 2). Similarly, the original cv. Traminer grapevine, grown in the field for many years without any visible decrease of plant vitality or berry production, showed only mild leafroll and mosaic symptoms. There were no changes on the woody cylinder
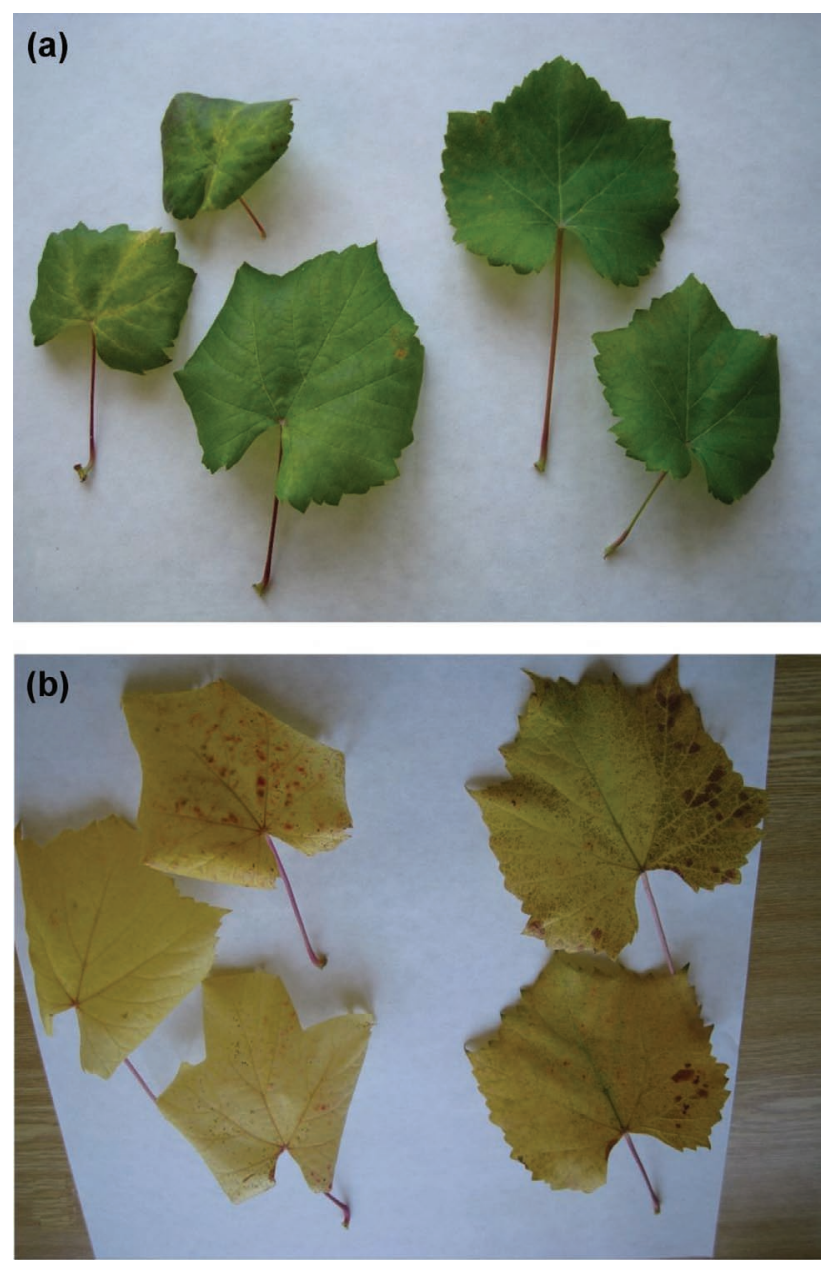

Fig. 2

Symptoms on leaves of multiple virus-infected LN33 grapevine The 3rd vegetation period after virus inoculation. Young leaves (A), old leaves (B), infected plant (left), healthy plant (right).

close to the point of grafting (rugose wood disease). We assume that the lack of symptoms could be caused by the occurrence of a mild strain of GVB.

Shi et al. (2004) also did not observe corky bark symptoms on LN33 infected with Australian isolates of GVB. They concluded that the corky bark disease was probably caused by a mixture of viruses.

Distribution of GLRaV-1, GVA, GVB, RSPaV, and a tymovirus in infected plants

GLRaV-1 was detected by ELISA in all 8 samples from two shoots of infected LN33 plant and in all 4 samples from infected Traminer plant (Table 2). It seems that the virus was present in all parts of the dormant grapevine canes, which 
Table 2. Distribution of GLRaV-1, GVA, GVB, RSPaV, and tymovirus in infected grapevine plants

\begin{tabular}{|c|c|c|c|c|c|c|c|c|c|c|}
\hline \multirow{2}{*}{\multicolumn{2}{|c|}{ Plant }} & \multicolumn{9}{|c|}{ Virus } \\
\hline & & \multicolumn{3}{|c|}{ GLRaV-1 } & \multicolumn{2}{|c|}{ GVA } & \multicolumn{2}{|c|}{ GVB } & \multirow{2}{*}{$\begin{array}{l}\text { RSPaV } \\
\text { RT-PCR }\end{array}$} & \multirow{2}{*}{$\begin{array}{l}\text { Tymovirus } \\
\text { RT-PCR }\end{array}$} \\
\hline Grapevine & Sample & $\begin{array}{c}\text { RT-PCR } \\
\text { Komínek } \\
\text { et al. } \\
(2005)\end{array}$ & $\begin{array}{l}\text { RT-PCR } \\
\text { Habili et } \\
\text { al. }(2003)\end{array}$ & ELISA & RT-PCR & ELISA & RT-PCR & ELISA & & \\
\hline \multirow{7}{*}{ LN 33} & Shoot 1, bottom, part A & + & + & + & + & + & + & + & + & + \\
\hline & Shoot 1, part B & - & + & + & + & + & + & + & + & + \\
\hline & Shoot 1, part C & - & + & + & + & + & + & + & + & + \\
\hline & Shoot 1, top, part D & + & + & + & + & + & + & + & + & + \\
\hline & Shoot 2, bottom, part A & - & + & + & + & - & - & - & + & + \\
\hline & Shoot 2, part B & - & + & + & + & - & + & + & - & - \\
\hline & Shoot 2, part C & - & + & + & + & - & + & + & - & - \\
\hline \multirow{5}{*}{$\begin{array}{l}\text { Traminer } \\
\text { (positive } \\
\text { control) }\end{array}$} & Shoot 2, top, part D & - & + & + & + & - & + & + & - & - \\
\hline & Bottom, part A & - & - & + & + & + & + & + & + & + \\
\hline & Part B & + & - & + & + & + & + & + & + & + \\
\hline & Part C & - & + & + & + & + & + & + & - & - \\
\hline & Top, part D & + & - & + & + & + & + & + & + & + \\
\hline
\end{tabular}

$(+)=$ positive,$(-)=$ negative .

makes this tissue suitable for serological virus detection. In contrast, two different RT-PCRs targeting different genome portions did not detect this virus in all of the samples. The RT-PCR according to Komínek et al. (2005) failed to detect GLRaV-1 in all 4 samples from shoot 2 of LN33. On the other hand, the RT-PCR according to Habili et al. (2003) consistently detected GLRaV-1 in all 8 samples from LN33. A partial positivity of similar extent was obtained with the two RT-PCRs for Traminer (positive control). Substantial intra-isolate diversity and evolution of viral populations in a perennial host, both biasing the specificity of RT-PCR primers, could explain the problems with RT-PCR detection.

GVA was detected by RT-PCR in all 8 samples from LN33 and in all 4 samples from Traminer. The virus was present in all parts of the dormant grapevine canes, which makes this tissue suitable for virus detection by RT-PCR. On the other hand, ELISA failed to detect the virus in all samples from the second shoot of LN33. This was probably caused by a lower virus concentration, under the detection limit of ELISA.

Detection of GVB by RT-PCR and ELISA gave identical results. The distribution was slightly irregular, with the absence of the virus in the lowest portion of shoot 2 of LN33.

The distribution of RSPaV and tymovirus as assayed by RT-PCR was identical showing intra-plant irregularity. One shoot from LN33 was entirely positive, while the other was positive only in the sample from its lowest part. The latter shoot might contain all the inoculated viruses in a low concentration, because it was negative also for GVA by ELISA.

We conclude that dormant canes sampled before the beginning of the vegetation period are, in most cases, suitable targets for detection of grapevine viruses by ELISA and RT-PCR.

For GLRaV-1 detection, ELISA unexpectedly appears to be more effective than RT-PCR probably due to an insufficient specificity of primers, not reflecting the actual genetic variability of the virus (Komínek et al., 2005).

Distribution of viruses in a long-term infected grapevine plant showed different degrees of irregularity, depending on individual viruses. As differences in the virus presence between individual shoots of the same plant have been noted, an unambiguous conclusion concerning the higher probability of their occurrence in the lower or upper portions of the plant cannot be made. Thus, to accurately check the sanitary status of any grapevine tested, several random samples from different parts of tested plant have to be analyzed.

Acknowledgements. This work was supported by the projects Nos. MZe 0002700604 and QG50083, Program PP1-T1 "Production and processing of agricultural products" of Ministry of Agriculture of the Czech Republic, M.G. was supported by the grant No. 2/0030/10 from the Scientific Grant Agency of Ministry of Education of Slovak Republic and Slovak Academy of Sciences. 


\section{References}

Adams MJ, Antoniw JF, Bar-Joseph M, Brunt AA, Candresse T, Foster GD, Martelli GP, Milne RG, Zavriev SK, Fauquet CM (2004): The new plant virus family Flexiviridae and assessment of molecular criteria for species demarcation. Arch. Virol. 149, 1045-1060.

Anonymous (2008): Pathogen-tested material of grapevine varieties and rootstocks. EPPO Bull. 38, 422-429. doi:10.1111/ j.1365-2338.2008.01258.x

Dovas CI, Katis NI (2003): A spot multiplex nested RT-PCR for the simultaneous and generic detection of viruses involved in the aetiology of grapevine leafroll and rugose wood of grapevine. J. Virol. Methods 109, 217-226. doi:10.1016/ S0166-0934(03)00074-0

Garcia-Arenal F, Fraile A, Malpica JM (2001): Variability and genetic structure of plant virus populations. Ann. Rev. Phytopathol. 39, 157-186. doi:10.1146/annurev. phyto.39.1.157

Goszczynski DE, Jooste AEC (2003): Identification of divergent variants of Grapevine virus A. Eur. J. Plant Pathol. 109, 397-403. doi:10.1023/A:1023555018700

Habili N, Afsharifar A, Symons RH (2003): First detection of an Ampelovirus, a Maculavirus and two vitiviruses in Iranian table grapes. Ext. abstr. 14th ICVG meeting, September 12-17, 2003, Locorotondo (Bari), Italy, pp. 162-163.

Habili N, Farrokhi N, Lima MF, Nicholas P, Randles JW (2006): Distribution of Rupestris stem-pitting-associated virus variants in two Australian vineyards showing different symptoms. Ann. Appl. Biol. 148, 91-96. doi:10.1111/ j.1744-7348.2006.00041.x

Habili N, Komínek P, Little A (2007): Grapevine Leafroll-Associated Virus 1 as a common grapevine pathogen. Plant Viruses 1, 63-68.

Komínek P, Glasa M, Bryxiová M (2005): Analysis of the molecular variability of Grapevine leafroll-associated virus 1 reveals the presence of two distinct virus groups and their mixed occurrence in grapevines. Virus Genes 31, 247-255. doi:10.1007/s11262-005-3236-1
Komínek P (2008): Distribution of grapevine viruses in vineyards of the Czech Republic. J. Plant Pathol. 90, 357-358.

Martelli GP, Sabanadzovic S, Abou-Ghanem Sabanadzovic N, Edwards MC, Dreher T (2002): The family Tymoviridae. Arch. Virol. 147, 1837-1846. doi:10.1007/ s007050200045

Martelli GP, Boudon-Padieu E (2006): Infectious agents of grapevines. In: Directory of infectious diseases of grapevines and Viroses and virus-like diseases of the grapevine: Bibliographic report 1998-2004. Options Méditerranéennes Série B: Studies and Research 55, 15-16.

Meng B, Pang S, Forsline PL, McFerson JR, Gonsalves D (1998): Nucleotide sequence and genome structure of grapevine rupestris stem pitting associated virus-1 reveal similarities to apple stem pitting virus. J. Gen. Virol. 79, 2059-2069.

Minafra A, Hadidi A (1994): Sensitive detection of grapevine virus A, B, or leafroll-associated III from viruliferous mealybugs and infected tissue by cDNA amplification. J. Virol. Methods 47, 175-188. doi:10.1016/0166-0934(94)90076-0

Nassuth A, Pollari E, Helmeczy K, Stewart S, Kofalvi SA (2000): Improved RNA extraction and one-tube RT-PCR assay for simultaneous detection of control plant RNA plus several viruses in plant extracts. J. Virol. Methods 90, 37-49. doi:10.1016/S0166-0934(00)00211-1

Rosa C (2007): Etiology of „rugose wood complex“ and functional analysis of Grapevine virus D. PhD Thesis. University of California, Davis, 2007, 220 pages; AAT 3261187.

Sabanadzovic S, Abou-Ghanem N, Castellano MA, Digiaro M, Martelli GP (2000): Grapevine fleck virus-like viruses in Vitis. Arch. Virol. 145, 553-565. doi:10.1007/ s007050050046

Saldarelli P, Minafra A, Martelli GP (1996): The nucleotide sequence and genomic organization of grapevine virus $B$. J. Gen. Virol. 77, 2645-2652. doi:10.1099/0022-131777-10-2645

Shi BJ, Habili N, Gafny R, Symons RH (2004): Extensive variation of sequence within isolates of Grapevine virus B. Virus Genes 29, 279-285. doi:10.1023/B: VIRU.0000036388.41242.c1 